\title{
ABNORMAL UTERINE BLEEDING IN ADOLESCENTS: CURRENT STATE OF THE PROBLEM
}

DOI: $10.36740 /$ WLek202008130

\author{
Iryna 0. Tuchkina, Liudmyla A. Vygivska, Anastasia A. Novikova \\ KHARKIV NATIONAL MEDICAL UNIVERSITY, KHARKIV, UKRAINE
}

\begin{abstract}
The aim: To summarize the literature data on abnormal uterine bleeding in adolescents.

Materials and methods: This article presents an assessment of 32 literary sources from 2003 to 2018, which raise the issues of etiology and pathogenesis of abnormal uterine bleeding in adolescents. Abnormal uterine bleeding in adolescents (AUBA) is a risk factor for disorders of menstrual and generative function, hormone-related abnormalities in the reproductive age. Despite the progress made in the development of methods for the diagnosis and treatment of AUBA, the criteria for selecting a particular method of diagnosis and therapy have not yet been made sufficiently clear.

Conclusions: AUBA is a complex polyetiological disease affecting all parts of the hypothalamic-pituitary-adrenal-ovarian system. It has a negative impact on the girl's health and quality of life. Abnormal uterine bleeding is a "signal" to the body of an organic or functional disorder. If this feature is ignored, the pathology can progress and lead to severe consequences. The urgency of the problem of AUBA is further explained by the fact that this disease indicates the presence of serious disorder of the reproductive system, which in the future may be transformed into impaired reproductive function.
\end{abstract}

KEY WORDS: abnormal uterine bleeding, puberty, polyetiological disease

Wiad Lek. 2020;73(8):1752-1755

\section{INTRODUCTION}

In the last decade, the problem of protecting the reproductive health of children and adolescents, as well as the prevention and treatment of gynecological diseases in childhood has attracted the attention of not only pediatric gynecologists, but also of other physicians. Abnormal uterine bleeding in adolescents (AUBA) is one of the most common forms of reproductive system abnormalities during puberty. Adolescent girls have an instability of the functional state of higher nervous activity, which controls the mechanisms of regulation of the developing reproductive system, and the receptor apparatus of the uterus and ovaries is in the period of development [1].

\section{THE AIM}

To summarize the literature data on abnormal uterine bleeding in adolescents.

\section{MATERIALS AND METHODS}

This article presents an assessment of 32 literary sources from 2003 to 2018, which raise the issues of etiology and pathogenesis of abnormal uterine bleeding in adolescents.

AUBA is a risk factor for disorders of menstrual and generative function, hormone-related abnormalities in the reproductive age. Despite the progress made in the development of methods for the diagnosis and treatment of AUBA, the criteria for selecting a particular method of diagnosis and therapy have not yet been made sufficiently clear.

\section{REVIEW AND DISCUSSION}

The problem of AUBA is due to the pronounced impact on health of adolescents, resulting in anemization, psycho-emotional disorders and disorders of menstrual function and infertility in adulthood [2,3].

At present, the formation of adolescent health is influenced by a set of adverse factors, particularly technogenic, socio-economic, biochemical and others. According to I.O. Tuchkina et al. an increase in the number of adolescents with menstrual dysfunction (MD) may be associated with a worsening of environmental situation in the country, with unfavorable social and living conditions of some population groups, with an increase in the number of children with congenital and chronic somatic diseases, etc. [2].

It is important to identify the causes of MD in adolescents, which can help prevent future relapses and address reproductive health problems in marriage.

AUBA is the most severe disorder, with the incidence varying between $2.5-38.2 \%$ of all gynecological diseases in adolescent girls [4].

AUBA is a generic term that involves changes in regularity and frequency of menstruation, the duration of bleeding or the amount of blood loss $[5,6]$. The causes of MD in adolescents are quite diverse: mental stress, emotional and physical overload, fatigue, hypovitaminosis, glandular dysfunction, acute or chronic infectious diseases, somatic disorders, disrupted work and rest regimes, complications in mothers during pregnancy and childbirth, infectious diseases of parents, artificial feeding, etc. [7-11]. 
The course of pregnancy and childbirth in the mother determines the reproductive health of the girl [7]. MD is known to be more frequent in girls born to mothers whose pregnancy was complicated by habitual miscarriage, preeclampsia, placental dysfunction, which contributed to fetal growth restriction $[7-9,12]$.

AUBA pathogenesis is formed by anovulation, progesterone deficiency, prolongation of luteinizing hormone and testosterone secretion, which is characteristic of puberty [13]. In this case, the changes occur secondary to vegetative instability and intensification of the adaptive-compensatory capacity of the adolescent organism, which is not always taken into account by gynecologists [14].

V.A. Dynnik, 2014 [15], points to impaired blood coagulation as one of the causes of AUB. It is believed that bleeding in puberty is the first clinical manifestation of hemostatic system disorders. A study of the system of hemostasis in healthy girls and girls with MD revealed changes that depend on the duration of the disease and the volume of blood loss: girls with minor prolonged bleeding were found to have compensatory hypercoagulation [16].

Intrauterine hemostasis during menstruation is achieved not only by the formation of small blood clots in spiral arterioles, but also by contraction of their smooth muscles [4]. Endometrial endothelial factors, namely endothelin transforming growth factor and tumor necrosis factor are powerful vasoconstrictors. Insufficient production of these biologically active substances may increase the duration of bleeding and thus contribute to the development of menorrhagia [5]. In addition to changes in the vascular wall, the development of bleeding is facilitated by increased sensitivity of the endometrium to estrogens, which leads to hyperplastic processes [17].

AUBA is considered to be a result of disruption of normal secretion of hypothalamic, pituitary and ovarian hormones secondary to failure of the neuro-receptor apparatus of different parts of the reproductive system during its age-related functional immaturity $[6,8]$.

Another trigger in AUBA pathogenesis is mental trauma and physical activity. The stress effect is accompanied by activation of the hypothalamic-pituitary-adrenal system, resulting in impaired secretion of gonadoliberin and, accordingly, gonadotropic hormones. As a result, there is persistence of the follicles, which leads to hyperestrogenemia. Increased secretion of adrenocorticotropic hormone in stress can lead to a decrease in secretion of luteinizing hormone (LH), thereby disrupting ovulation, which also leads to persistence or atresia of the follicles. Regular psycho-traumatic impact is a particularly unfavorable factor, as long emotional tension is accompanied by increased activity of the adrenal glands $[10,11]$. Such a negative impact can be associated with an unfavorable atmosphere in the family, problems with peers, excessive workload in schools, unbalanced nutrition, etc. [11]. Most often there is a combination of several factors that interfere with the establishment of correct relationships in the nervous-endocrine system of adolescents $[10,18]$.

The physiological course of puberty is characterized by a regular change in hormonal parameters. A study of en- docrine parameters in adolescent girls revealed a gradual increase in the concentration of hormones of the pituitary gland, ovaries and adrenal glands, except prolactin [19]. The content of $\mathrm{LH}$, follicle stimulating hormone (FSH) and estradiol significantly increases $1-2$ years before the first menstrual period. Prolactin levels rise 2-3 years before menarche [17]. There is also an opinion on the role of prolactin peaks in the initiation of the process of puberty [3]. In $15 \%$ of cases, there may be transient hyperprolactinemia, which does not require specific therapy with dopamine agonists [19].

According to modern concepts, the study of the level of gonadotropic and sexual hormones of the blood allows to obtain the most accurate information about the status of various links of the endocrine system. Hormonal homeostasis in AUBA does not have a clearly specific constancy, but there may be different variations of its changes, depending on the menstrual age and duration of the disease [5]. AUBA is characterized by impaired LH/FSH ratio: the first stage of AUB formation may have a tendency to activate the function of the pituitary gland, and in recurrent bleeding, a tendency to decrease gonadotropic function [3]

Relative hyperestrogenism in puberty caused by insufficiency of the luteal phase of the cycle results in the absence of adequate secretory transformation and the development of hyperplastic processes of the endometrium [17]. Increased systemic production of vascular endothelial growth factor in patients with uterine bleeding may lead to dysregulation of cyclic angiogenesis. It can cause defective secretory transformation of the endometrium, impaired folliculogenesis in the ovaries, anovulation and relative hyperestrogenism [19].

The association of AUBA with menstrual age has been revealed. AUBA more often occurs with the onset of menarche or in the first year thereafter [4,8,20-22].

The study of case histories showed that $98.1 \%$ of girls with AUBA had at least 3-4 infections in the past. They also often had colds $-61.3 \%$, and tonsillitis $-42.0 \%[12,22,23]$.

Given the morpho-functional characteristics, there are ovulatory and anovulatory AUB. Ovulatory uterine bleeding can occur as a result of folliculin phase insufficiency, disorders of the pituitary system, stress conditions, neuropsychiatric disorders, vitamin deficiency, extragenital diseases, impaired blood coagulation. Any abnormalities in one of the links in this complex system lead to changes in the ovarian cycles and, due to this, to the disruption of steroid hormones production [19]. In such patients, the menstrual cycle is reduced to 14-21 days by reducing the duration of the folliculin phase to 7-8 days with luteal phase preserved [24]. Luteal phase deficiency occurs as a result of LH deficiency and implies defective development of the yellow body or its premature death. Hemorrhage into the developing yellow body is also possible, or the presence of insufficient endometrial reactivity, which is not amenable to complete secretory transformation and cannot be completely ejected. The duration of the cycle over time is preserved, the folliculin phase is complete, but the lutein is insufficient, resulting in more or less abundant spotting before and after menstruation [20]. 
Ovulatory bleeding also includes bleeding during ovulation, lasting from several hours to 3-4 days. They are caused by a violation of the ratio of estrogens and progesterone towards estrogen reduction. Ovulatory bleeding may alternate with anovulatory ones [6].

Most often, adolescents have anovulatory bleeding. The pathogenic mechanism of anovulatory uterine bleeding involves the absence of ovulation and secretory transformation of the endometrium with the development of hyperplastic processes. Anovulatory bleeding is clinically characterized by a period of menstrual delay, which is replaced by bleeding lasting more than 7 days. It occurs with long-term persistence of the follicle, short-term rhythmic persistence of the follicle, prolonged functioning of atretic follicles [3]. This type of AUB is conditioned by the absence of a cyclic ovulatory peak of gonadotropins while maintaining a level of their basal secretion sufficient to stimulate the follicle phase of the cycle. Due to the absence of ovulation, there is a prolonged estrogenic stimulation of the endometrium, resulting in excessive growth of the functional layer of the endometrium, its loosening, congestive plethora, expansion of the lumen of the glands to cystic cavities. Estrogen levels decrease as a result of follicular atresia causing bleeding, considerable both in duration and in volume, as these patients also have increased vascular permeability due to abnormalities in the enzyme system $[15,22,25,26]$.

The most severe complications of AUBA are acute blood loss syndrome, which, although infrequent, results in fatalities in somatically healthy girls, as well as anemic syndrome, the severity of which is determined by the intensity of AUB and its duration [27]. Mortality in adolescent girls with AUBA is most often due to acute multiorgan disorders due to severe anemia and hypovolemia, complications of transfusion of native blood and its components, the development of irreversible systemic disorders secondary to chronic iron deficiency. Posthemorrhagic anemia with prolonged and profuse bleeding affects the performance and studying of adolescents. Patients suffer from weakness, fatigue, dizziness. They often have variations in the blood coagulation and anti-coagulation criteria. AUB can further lead to menstrual and reproductive disorders, hormone-related diseases.

To prevent the development of AUBA, it is advisable to distinguish groups of adolescent girls at risk of prolonged persistence of anovulatory menstrual cycles: hemorrhagic events in personal and family history, menstruation at the age of 10 and after 13 years, the presence of inflammatory diseases, malnutrition, thyroid diseases, severe mental stress, disturbance of biorhythms, professional sports, especially during the first years of menarche [28-30].

Adolescent girls often have difficulty assessing normal menstrual cycles or bleeding without knowing what is normal. Patients often do not inform doctors and do not want to discuss the problem of menstrual disorders or missed periods with their parents or guardians $[31,32]$. Often this causes the patient to visit the gynecologist late. On the other hand, this problem is often underestimated by GPs, pediatricians, and gynecologists. Adolescent AUBA is an urgent problem in modern gynecology, since the treatment and rehabilitation of these patients are important because of disease recurrences, which significantly worsen the prognosis for reproductive function, which is a social and economic problem.

\section{CONCLUSIONS}

AUBA is a complex polyetiological disease affecting all parts of the hypothalamic-pituitary-adrenal-ovarian system. It has a negative impact on the girl's health and quality of life. Abnormal uterine bleeding is a "signal" to the body of an organic or functional disorder. If this feature is ignored, the pathology can progress and lead to severe consequences. The urgency of the problem of AUBA is further explained by the fact that this disease indicates the presence of serious disorder of the reproductive system, which in the future may be transformed into impaired reproductive function.

Patients with uterine bleeding in puberty should be monitored by a pediatric gynecologist until stable normalization of menstrual function for one year and reaching the age of 18 years.

\section{REFERENCES}

1. Özge Y., Yüce Y., Orhun Ç.M. Overview of Abnormal Uterine Bleeding in Adolescents: Diagnosis and Management. International Journal of Women's Health and Reproduction Sciences. 2017;5(3):158-63.

2. Tuchkina I.A., Zobina I.Yu., Lesovaya M.A., Tuchkina M.Yu. Patologiya pubertata i realizaciya reproduktivnogo potenciala zhenskogo organizma: kliniko-terapevticheskie paralleli [Pathology of puberty and the realization of the reproductive potential of the female body: clinical and therapeutic parallels]. Zdorove zhenshiny. 2010;3(49):175-8. (Ru)

3. Başaran H.O., AkgülS., Kanbur N.0., et al. Dysfunctional uterine bleeding in adolescent girls and evaluation of their response to treatment. Turk J Pediatr. 2013;55(2):186-9.

4. Tuchkina I.A., Gylenko Zh.O., Kalashnyk N.V., Vygovska L.A. Klinikogormonalnaya harakteristika i terapiya devushek s giperplaziej endometriya na fone anemii [Clinical hormonal characteristics and therapy of girls with endometrial hyperplasia and anemia]. International Medical Journal. 2014;20(3):87-91. (Ru)

5. Uvarova E.V. Anomalnye matochnye krovotecheniya [Abnormal uterine bleeding in puberty]. Pediatric and Adolescent Reproductive Health. 2013;3:73-88. (Ru)

6. Sibirskaya E.V., Bogdanova E.A., Sashkina A.E. Matochnoe krovotechenie pubertatnogo perioda — osobennosti gormonalnogo fona [Abnormal uterine bleeding in young women - hormonal assessment]. System analysis and management in biomedical systems. 2011;10(2):435-38. (Ru)

7. Dynnik V.O., Sulima T.N. Vpliv perinatalnogo periodu na osoblivosti klinichnogo perebigu pubertatnih matkovih krovotech [He impact of perinatal period on the character of pubertal uterine bleeding clinical course]. Perinatology and pediatric. 2010;4:37-9. (UA)

8. Dinnik V.0. Klinichnij perebig pubertatnih matkovih krovotech v zalezhnosti vid harakteru statevogo dozrivannya [Clinical interruption of pubertal uterine bleeding in the bedding due to the nature of the statutory monitoring]. Visnik nauk. doslidzhen. 2005;2:129-31. (UA) 
9. Saveleva G.M. Ginekologiya: nacionalnoe rukovodstvo [Gynecology: national leadership]. Saveleva G.M., Suhih G.T., Kulakov V.I., ed. Kratkoe izdanie. Moskva: GEOTAR-Media; 2013. p. 193-204. (Ru)

10. Akarachkova E.S., Kotova O.V., Vershinina S.V., Ryabokon I.V. Stress i rasstrojstva adaptacii [Stress and adjustment disorders]. Lechashij vrach. 2014;6:61-5. (Ru)

11. Anikhovskaya I.A., DvoenosovV.G.,Zhdanov R.I. etal. Psihoemocionalnyj stress kak klinicheskaya model nachalnoj fazy obshego adaptacionnogo sindroma. [Emotional stress as a clinical model to study the pathogenesis of the initial phase of the general adaptation syndrome]. Pathological physiology and experimental therapy. 2015;59(4):87-92. doi: 10.25557/0031-2991.2015.04.87-92. (Ru)

12. Tuchkina I.A, Tisyachka G.M. Nekotorye patogeneticheskie osobennosti techeniya pubertata u devochek-podrostkov $s$ vospaleniem genitalij na fone ekstragenitalnoj patologii [Some features of pathogenesis of puberty in adolescent girls with genital inflammation and extragenital pathology]. Scientific bulletins of Belgorod State University. Series: Medicine. Pharmacia. 2014;4(175):79-82. (Ru)

13. Munro M.G. Abnormal uterine bleeding. Cambridge, UK: Cambridge University Press; 2010.

14. Shcherbina I.N., Dinnik A.A. Giperplasticheskie processy v endometrii u devochek $s$ anomalnymi matochnymi krovotecheniyami rannego vozrasta [Hyperplastic processes of endometrium in girls with abnormal uterine bleeding]. Health - the base of human potential: problems and ways to their solution. 2015;10(2):468-9. (Ru)

15. Dynnik V.0. Katamnez hvorih na pubertatni matkovi krovotechi z urahuvannyam zastosuvannya negormonalnoyi i gormonalnoyi terapiyi [Catamnesis of patients with pubertal uterine bleedings in terms of use of non-hormonal and hormonal therapy]. Child health. 2014;2:31-4. (UA)

16. Dynnik V.A. Narusheniya dinamicheskogo ravnovesiya v sisteme svertyvaniya krovi pri anomalnyh matochnyh krovotecheniyah pubertatnogo perioda [Breach dynamic equilibrium in blood coagulation system under abnormal uterine bleeding puberty]. Scientific bulletins of Belgorod State University. Medicine. Pharmacia. 2015;32(22):73-80. (Ru)

17. Serova V.N. Klinicheskie rekomendacii. Akusherstvo i ginekologiya [Clinical recommendations. Obstetrics and gynecology]. Serova V.N., Suhih G.T., ed. 4-e izd., pererab. i dop. Moskva: GEOTAR-Media; 2014. p. 678-703. (Ru).

18. Ilyina L.I., Serdakova K.G. Stress i umenie im upravlyat [Technologies to overcome stressful situations in the work of nursing staff]. Medicinskaya sestra. 2015;7:42-4. (Ru)

19. Tatarchuk T.F., Solskij Ya.P. Endokrinnaya ginekologiya [Endocrine gynecology]. Kiev: Zapovit; 2003. (Ru)

20. Tatarchuk T.F., Cossey N.V., Redko N.A., Dzhupin V.A. Diagnostika i lechenie anomalnyh matochnyh krovotechenij [Diagnosis and treatment of abnormal uterine bleeding]. Reproductive endocrinology. 2014;5:22-32. (Ru)

21. Tuchkina I., Zobina L., Gilenko Z., Vigovskaya L. Course of pregnancy in women with uterine bleeding during puberty. In:XIII National Congress On Obstetrics \& Gynecology \& National Congress Of Midwifes; 2014 March, 13-16; Sofia, Bulgaria. Sofia; 2014. p. 39-42

22. Tuchkina I.0. Etapna reabilitaciya pidlitkiv z ginekologichnimi zahvoryuvannyami ta yunih vagitnih z ekstragenitalnoyu patologiyeyu [Staged rehabilitation of adolescents with gynecological diseases and young pregnant women with extragenital pathology] [disertaciya]. Kharkiv: Kharkivskij derzhavnij medichnij universitet; 2007.
23. Tuchkina I.A., Tisyachka G.M. Kompleksnaya terapiya podrostkov $s$ vospaleniem zhenskih polovyh organov s uchetom haraktera ekstragenitalnoj patologii [Complex treatment of adolescents with inflammation of female genitals and extragenital pathology]. Tavricheskiy medico-biologicheskiy vestnik. 2012;15(2)315-18. (Ru)

24. Bogdanova E.A. Prakticheskaya ginekologiya molodyh [Practical gynecology of young]. Moskva: Medicinskaya kniga; 2011. (Ru)

25. Estcourt L.J., Desborough M., Brunskill S.J. et al. Antifibrinolytics (lysine analogues) for the prevention of bleeding in people with haematological disorders. Cochrane Database Syst Rev. 2016;3:CD009733. doi: 10.1002/14651858.CD009733.pub3.

26. Gurkin Yu.A. Ginekologiya podrostkov [Gynecology of adolescents]. Rukovodstvo dlya vrachej. Sankt-Peterburg: IKF «Foliant»; 2010. (Ru)

27. Elmaoğulları S., AycanZ. Abnormal Uterine Bleeding in Adolescents.J Clin Res Pediatr Endocrinol. 2018;10(3):191-197. doi: 10.4274/jcrpe.0014.

28. Uvarova E.V. Anomalnye matochnye krovotecheniya pubertatnogo perioda [Abnormal uterine bleeding in puberty]. Pediatric and Adolescent Reproductive Health. 2018;(1):64-91. (Ru)

29. Adamyan L.V, Petryaykina E.E., Sibirskaya E.V., Osipova G.T., Pivazyan L.G. Anomalnye matochnye krovotecheniya pubertatnogo perioda u devochek-podrostkov: vedenie, diagnostika i lechenie [Abnormal uterine bleeding during puberty in adolescent girls: the management, diagnosis and treatment]. Russian Journal of Human Reproduction = Problemy reproduktsii. 2019;25(3):99-103. https://doi.org/10.17116/repro20192503199. (Ru)

30. Peacock A., Alvi N.S., Mushtaq T. Period problems: disorders of menstruation in adolescents. Arch Dis Child. 2012 Jun;97(6):554-60. doi: 10.1136/adc.2009.160853.

31. ACOG Committee Opinion No. 651: Menstruation in Girls and Adolescents: Using the Menstrual Cycle as a Vital Sign. Obstet Gynecol. 2015;126(6):1328. doi: 10.1097/A0G.0000000000001210.

32. Diaz A., Laufer M.R., Breech L.L. Menstruation in girls and adolescents: using the menstrual cycle as a vital sign. Pediatrics. 2006 Nov;118(5):2245-50.

\section{ORCID and contibutionship:}

Iryna O. Tuchkina: 0000-0003-4280-1474

Liudmyla A. Vygivska: 0000-0002-9389-4845 A,D,F

Anastasia A. Novikova: 0000-0003-3820-3500 ${ }^{B, E}$

\section{Conflict of interest:}

The Authors declare no conflict of interest.

\section{CORRESPONDING AUTHOR}

\section{Liudmyla A. Vygivska}

Kharkiv National Medical University

Nauki Av., 4, 61000, Kharkiv, Ukraine

tel: +380509675487

e-mail: liudmilavygovskaya@gmail.com

Received: 07.03.2020

Accepted: 01.07.2020

A - Work concept and design, B - Data collection and analysis, C - Responsibility for statistical analysis,

D-Writing the article, E-Critical review, $\mathbf{F}$ - Final approval of the article 